\title{
Effects of experimental eutrophization on zooplankton community
}

Efeitos da eutrofização experimental sobre a comunidade zooplanctônica

\author{
Ana Maria Alves de Medeiros ${ }^{1}$, Cyntya Eustáquio de Sousa², \\ Maria Cristina Crispim ${ }^{1}$ and Ana Karla Araújo Montenegro ${ }^{1}$
}

\author{
'Área de Concentração Zoologia, Programa de Pós-graduação em Ciências Biológicas, \\ Centro de Ciências Exatas e da Natureza - CCEN, Universidade Federal da Paraíba - UFPB, \\ Cidade Universitária, CEP 58059-900, João Pessoa, PB, Brazil \\ e-mail: ana.maria.bio@gmail.com; ccrispim@hotmail.com; biokarla_21@hotmail.com \\ ${ }^{2}$ Programa de Iniciação Científica - PIBIC, Centro de Ciências Exatas e da Natureza - CCEN, \\ Universidade Federal da Paraíba - UFPB, Cidade Universitária, CEP 58059-900, João Pessoa, PB, Brazil \\ e-mail: cyntya_sousa@hotmail.com
}

\begin{abstract}
Aims: The present study evaluated the role that increased nutrient concentrations play on zooplankton community, by employing an experimental laboratory approach. Methods: Experiments were conducted in the laboratory, where three trophic state conditions were simulated, namely, mesotrophic, eutrophic and hypereutrophic. Each treatment was replicated three times and individuals of Brachionus urceolaris (10 individuals), Hexarthra mira (5) (Rotifera), Latonopsis sp. (10), Moina minuta (10) (Cladocera) and Thermocyclops sp. (5) (Copepoda) were introduced to each replicate. On the first experiment day, and at 7-day intervals for a 14-day period (totaling three evaluations), all water content was collected from each container and filtered to determine the densities of each zooplankton species. Two-way MANOVA and one-way ANOVA designs were used to determine zooplankton density fluctuations among treatments and throughout the study period. Further, Generalized Linear Models (GLMs) were employed to assess how environmental factors affected zooplankton numbers. Phytoplankton composition was also determined in the beginning and in the end of the experiment. Results: B. urceolaris and copepod nauplii, which are typical of eutrophic environments, showed higher densities on the eutrophic and hypereutrophic treatments. Furthermore, cyanobacteria such as Aphanothece sp. and Merismopedia sp. were recorded on the eutrophic and hypereutrophic treatments, respectively. Conclusions: Similarly to what is frequently observed in the wild, the eutrophic treatment showed higher densities of particular zooplankton species which are known to temporarily benefit from an increase in trophic concentrations. Positive or negative responses from zooplankton dynamics (but also phytoplankton species), provide an important bioindicator framework. Furthermore, results of the present study outline the need for implementing recovery measures on aquatic environments subject to constant nutrient inputs.
\end{abstract}

Keywords: zooplankton, trophic states, phytoplankton, laboratory experiments.

Resumo: Objetivos: O presente estudo avaliou os efeitos do aumento na concentraçáo de nutrientes sobre a comunidade zooplanctônica, através de experimentos laboratoriais. Métodos: Os experimentos foram realizados em laboratório, onde três estados tróficos foram simulados, a saber, mesotrófico, eutrófico e hipereutrófico. Cada tratamento foi replicado três vezes, e indivíduos de Brachionus urceolaris (10 indivíduos), Hexarthra mira (5) (Rotifera), Latonopsis sp. (10), Moina minuta (10) (Cladocera) e Thermocyclops sp. (5) (Copepoda) foram introduzidos em cada réplica. Durante o primeiro dia de experimento, e a cada sete dias de intervalo durante 14 dias (totalizando três amostragens), toda a água foi coletada de cada aquário e filtrada, para a determinaçáo das densidades de cada espécie de zooplâncton. MANOVAs duas vias e ANOVAs de uma via foram empregadas para a determinação das variaçóes nas densidades de zooplâncton entre os tratamentos e ao longo do período de estudo. Ainda, Modelos Lineares Generalizados (MLGs) foram empregados para avaliar como fatores ambientais que influenciaram a densidade do zooplâncton. A composiçáo do fitoplâncton foi determinada no ínicio e no final do experimento. Resultados: $B$. urceolaris e náuplios de copépodos, típicos de ambientes eutrofizados, apresentaram maiores densidades nos tratamentos eutrófico e hipereutrófico. Ainda, cianobactérias como Aphanothece sp. e Merismopedia sp. foram registradas nos tratamentos eutrófico e hipereutrófico, respectivamente. Conclusóes: De maneira similar ao observado na natureza, o tratamento eutrófico apresentou maiores densidades de espécies do zooplâncton que se beneficiam do aumento na concentraçáo de nutrientes. Respostas positivas ou negativas na dinâmica do zooplâncton fornecem uma ferramenta bioindicadora eficaz. Ainda, os resultados do presente estudo enfatizam a necessidade de implementar medidas reparadoras em ambientes aquáticos sujeitos a entradas constantes de nutrientes.

Palavras-chave: zooplâncton, estados tróficos, fitoplâncton, experimentos em laboratório. 


\section{Introduction}

Eutrophization of lentic environments (i.e. reservoirs and lakes) is a natural process caused by a gradual increase in the concentration of nutrients, particularly, nitrogen and phosphorous (OECD, 1982; Esteves, 1998). Nevertheless, several human activities boost this process, modifying the environment at both landscape and community levels (see Kelly and Whitton, 1998; Figueirêdo et al., 2007).

When prompted by human activities, the origins of eutrophization are manifold, including urban, industrial and agricultural runoffs, which have profound effects on the physical, chemical and biological dynamics, and especially, on the trophic structure of the environment (Carpenter et al., 1985; Riegman, 1995). Therefore, eutrophization is a type of chemical pollution and, since increase in phytoplankton biomass is a direct effect of nutrients concentration, one of the primary effects of eutrophization is the rapid proliferation of algae, as acknowledged from several investigations (Anderson, 1989; Maresovic and Pucher-Petkovic, 1991; Scheffer, 1998; Silva, 1999; Anderson et al., 2002). As a consequence, this rapid phytoplankton growth may alter the overall trophic structure of the environment via trophic cascade interactions (Ravera, 1980; Seip, 1991; Scheffer, 1998) and, ultimately, drastically reduce water quality. In fact, a somewhat linear sequence is expected to occur with the rapid input of nitrogen and phosphorous, namely: 1) proliferation of diatoms, chlorophytes and cyanobacteria, 2) increase in the density of planktivores, and 4) decrease of water transparency and 5) decrease of dissolved oxygen (Esteves, 1998; Moss, 1998).

Several authors investigated the resulting cascade effects of increased nutrients on several environments worldwide (e.g. Maresovic and Pucher-Petkovic, 1991; Seip, 1991; Kelly and Whitton, 1998; Huszar et al., 1998; Forrester et al., 1999; Crispim et al., 2000; Bezerra-Neto, 2001; Anderson et al., 2002; Figueirêdo et al., 2007). These studies emphasize the central role played by zooplankton at transferring energy and, thus, linking primary producers to secondary and tertiary consumers. Furthermore, managing phytoplankton growth, particularly cyanobacterial blooms which present health risks for humans and livestock (Beasley et al., 1989; Aguiar and Azevedo, 1998), is a central objective in freshwater ecology.

The present study evaluated the effects of increased nutrient concentration (eutrophization) on some species of three major zooplankton groups (Rotifera, Cladocera and Copepoda) via experimental laboratory manipulations from different trophic states.

\section{Material and Methods}

\subsection{Experimental design and lab procedures}

The effects of increased nutrient concentrations (eutrophization) on the zooplankton community were experimentally tested under three simulated trophic states (mesotrophic, eutrophic and hypereutrophic).

Water used to conduct the experiments was collected on the Taperoá II reservoir, Taperoá city, Paraíba, Brazil (see Feliciano and Melo (2003) for detailed area description). Water was filtered through a $0.45 \mu \mathrm{m}$ GFC membrane, and nutrients (nitrogen and phosphorus compounds) were subsequently added to each treatment. Given the natural mesotrophic conditions of the water collected from the reservoir, nutrients were not added to the mesotrophic treatment.

In field, subsamples of collected water were stored in one-liter-capacity PVC bottles and acclimatized in ice for subsequent determination of initial nutrient concentrations (i.e. total nitrogen and total phosphorus), and also to validate trophic states (Table 1). Nutrient concentrations were determined following the procedures described by Rodier (1975), Mackereth et al. (1978) and Clesceri et al. (1998). Furthermore, the addition of nitrogen and phosphorous as a means to simulate desired trophic conditions was recently tested by Vieira et al. (2011) and proved to be an efficient laboratory approach.

Table 1. Initial concentration levels of nitrogen and phosphate $(\mu \mathrm{g} / \mathrm{L})$ employed on experimental treatments simulating three trophic state conditions.

\begin{tabular}{lcccc}
\hline \multirow{2}{*}{$\begin{array}{c}\text { Experimental } \\
\text { treatments }\end{array}$} & Ammonia & Nitrite & Nitrate & Phosphate \\
\cline { 2 - 5 } & 105.3 & 20.2 & 363.6 & 108.5 \\
Mesotrophic & 620.8 & 70.5 & 644.7 & 457.1 \\
Eutrophic & 2337.1 & 113.2 & 2923.9 & 479.1 \\
\hline
\end{tabular}


Three treatments following a gradient of increased nutrient concentrations were prepared for the experiments, namely: mesotrophic (T1), eutrophic (T2) and hypereutrophic (T3). Each treatment was prepared on 300-mL-capacity PVC container and replicated three times. On each replicate, a total of 40 zooplankton individuals from five species were introduced at the following proportions: Rotifera (Brachionus urceolaris Müller, 1773: 10 individuals; Hexarthra mira (Hudson, 1871): 5 individuals), Cladocera (Latonopsis sp.: 10 individuals; Moina minuta Hansen, 1899: 10 individuals) and Copepoda (Thermocyclops sp.: 5 individuals). Species identification followed Koste (1978) and Stemberg (1979) for Rotifera, ElmoorLoureiro (1997) for Cladocera, and Rocha and Matsumura-Tundisi (1976); Reid (1985); Silva (2003) and Silva and Matsumura-Tundisi (2005) for Copepoda.

Treatments were maintained under controlled photoperiod (12L (light): 12D (dark)), and constant humidity and temperature $\left(28^{\circ} \mathrm{C}\right)$ within a culture chamber during the study period (i.e. 14 days). Microalgae collected on the reservoir and cultivated in the laboratory were used to feed the zooplankton. On each treatment, zooplankton cultures were fed with microalgae at concentrations of $6.416 \times$ $10^{3}$ ind. $\mathrm{ml}^{-1}$ at three-day intervals. In the beginning of the experiment and at four-day intervals, a $1 \mathrm{~mL}$ subsample was collected from each replicate to determine food concentration (algal density) as a means of estimating the necessary amount of food to be subsequently added and, thus, maintaining samples with constant food concentrations. In the beginning of the experiment, microalgae were observed at the following proportions on all treatments: Scenedesmus acuminatus (Lagerheim) (22.7\% relative abundance), Scenedesmus bijugatus Kützing (38.5\%), Chorella sp. (9.2\%), unidentified algae (7.4\%), Aphanothece sp. (15\%), and Chrococus sp (7.2\%). Algal densities were determined by counting individuals on a Fuchs Rosenthal counting chamber under proper magnification. Identification followed; Silva (1999) and Bicudo and Menezes (2006). During three intervals (days 1, 7 and 14) each replicate was entirely filtered and densities of each zooplankton species determined. On the first day, individuals of all species were introduced to each container. Densities of each zooplankton species were determined on the $7^{\text {th }}$ and $14^{\text {th }}$ days.

\subsection{Data analysis}

The effects of eutrophization on zooplankton community were evaluated by comparing zooplankton abundance among days and among treatments. Normality and homogeneity of the data were tested using Shapiro-Wilk's and Levene's tests (Royston, 1983), respectively, and, when necessary, data was $\log _{\mathrm{x}+1}$-transformed. A two-way MANOVA design was employed to test the effects of trophic states (mesotrophic, eutrophic and hypereutrophic), sampling days $\left(1^{\text {st }}, 7^{\text {th }}\right.$ and $14^{\text {th }}$ days) and their interaction terms on zooplankton density with data from all species pooled together. Also, univariate ANOVAs were conducted to test the abundance of each species individually amongst trophic states and sampling days. On both procedures, Tukey's HSD was used to assess post-hoc differences when significant $\mathrm{p}$ levels were detected.

To determine the contribution of environmental factors to the observed variance in zooplankton abundance, Generalized Linear Models (GLMs) were conducted. Abundances of zooplankton species were tested as dependent variables, whereas $\mathrm{pH}$, water temperature and electric conductivity were tested as continuous independent variable and nutrient concentration was tested as categorical independent variable following concentration levels employed on the experimental treatments (mesotrophic, eutrophic and hypereutrophic).

\section{Results}

Density of $B$. urceolaris decreased on the $7^{\text {th }}$ experiment day on all treatments and persisted declining on the mesotrophic treatment. However, on the eutrophic and hypereutrophic treatments, density of this species increased after the $7^{\text {th }}$ day (Figure 1a). Nonetheless, no significant differences in the density of this species were detected among treatments and among sampling days (Table 2).

Density of $H$. mira decreased on the $7^{\text {th }}$ experiment day on the hypereutrophic treatment and subsequently increased. On the other hand, the density of this species increased on the $7^{\text {th }}$ day and subsequently decreased on the mesotrophic treatment (Figure 1b). Statistical analyses revealed significant differences among sampling days and for the interaction term between treatments and sampling days, but not amongst treatments alone (Table 2).

The cladoceran Latonopsis sp. showed a somewhat low variation in density on all treatments, but a slightly higher density was observed on the eutrophic treatment (Figure 1c), albeit statistical 
a)

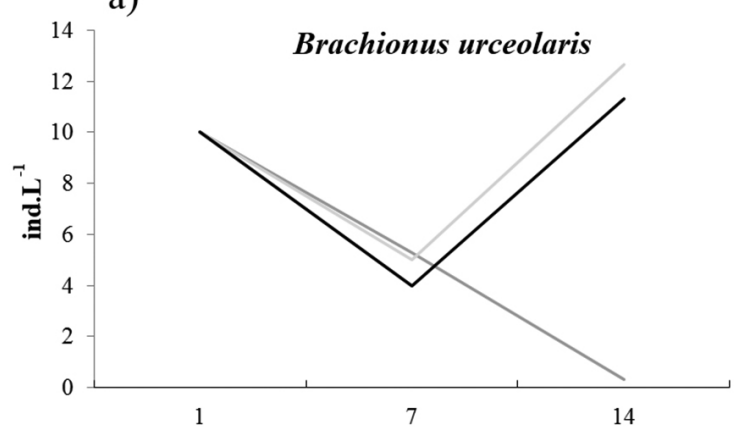

c)
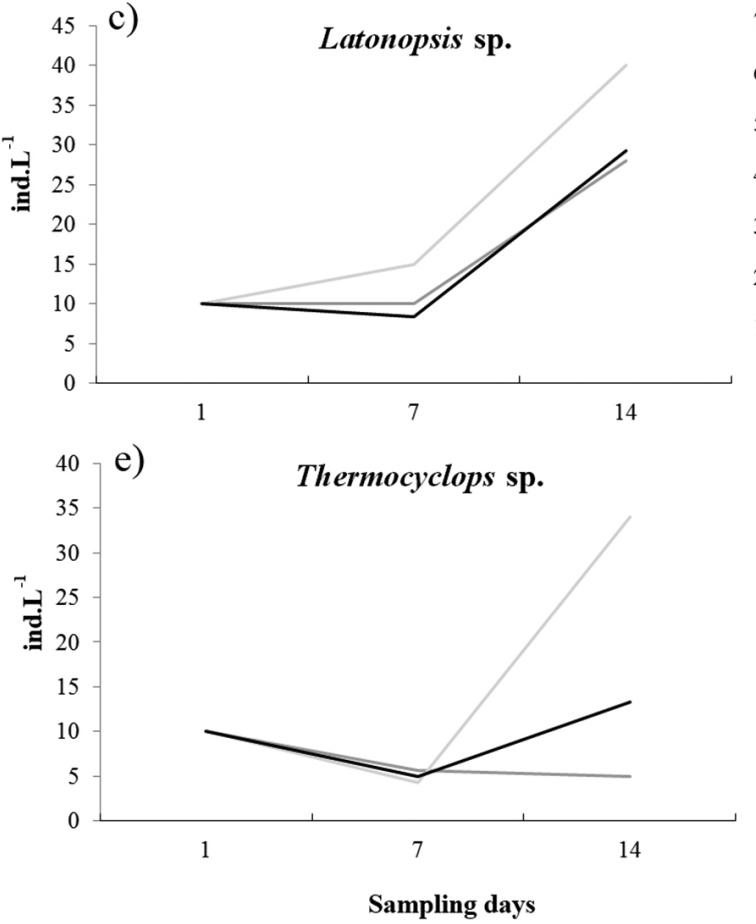

b)

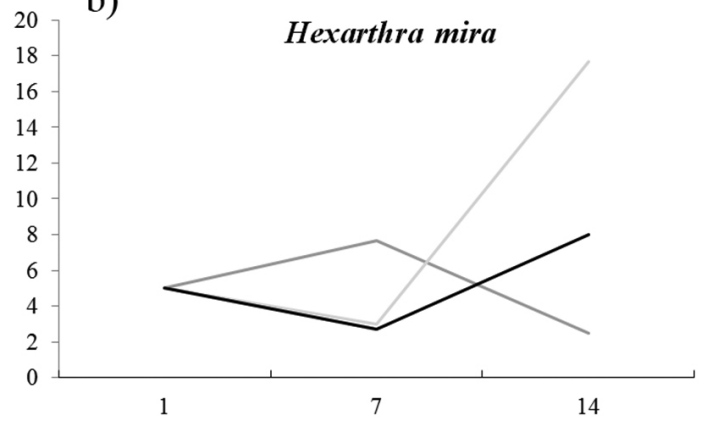

d)
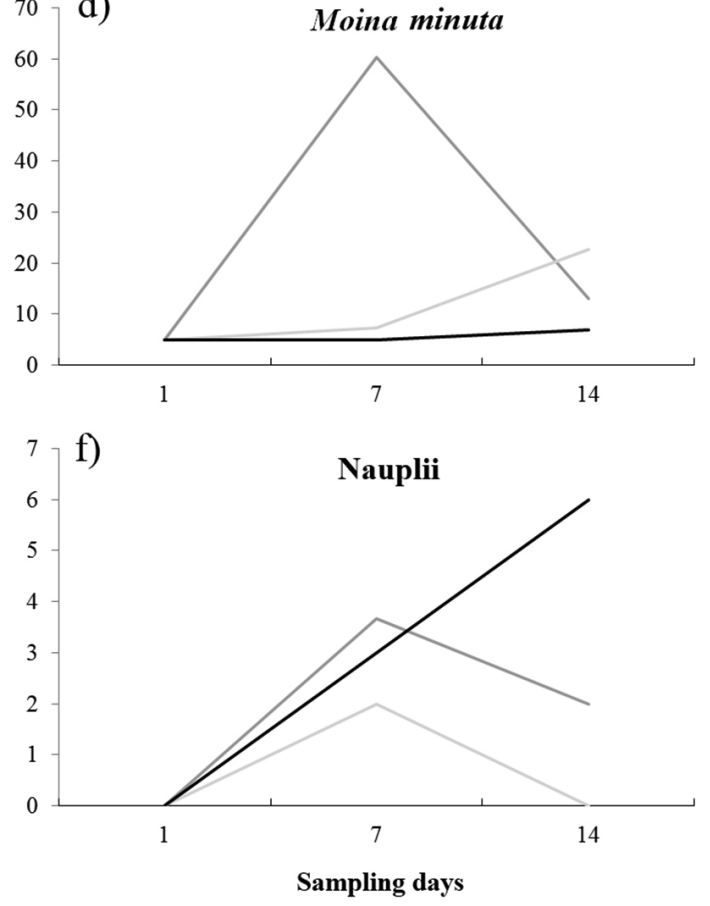

Figure 1. Temporal variations in the densities of Brachionus urceolaris (a), Hexarthra mira (b), Latonopsis sp. (c), Moina minuta (d), Thermocyclops sp. (e) and nauplii (f) on three experimentally simulated trophic conditions (mesotrophic, eutrophic and hypereutrophic).

analyses did not reveal significant differences (Table 2).

Density of $M$. minuta varied significantly among treatments and among sampling days (Figure 1d; Table 2). M. minuta showed a higher density on the $7^{\text {th }}$ experiment day on the mesotrophic treatment, decreasing drastically afterwards, whereas higher density was observed on the $14^{\text {th }}$ day on the eutrophic treatment. In hipereutrophic conditions densities remained similar along the experiment.

Density of the copepod Thermocyclops sp. initially decreased on all treatments, but subsequently increased on the eutrophic and hypereutrophic treatments (Figure 1e). On the mesotrophic treatment, density of Thermocyclops sp. decreased throughout the study period. Nonetheless, no significant differences were observed among treatments (Table 2).

A somewhat high density of nauplii was observed on the hypereutrophic treatment, particularly on the $14^{\text {th }}$ day, when compared to the other treatments (Figure 1f). Furthermore, the mesotrophic treatment, with low densities of adults and copepodites, showed higher nauplii density than the eutrophic treatment. Albeit to a smaller extent, a similar tradeoff between adults and nauplii was also observed on the hypereutrophic treatment. Statistical analyses revealed significant differences throughout the study period and among treatments regarding nauplii density (Table 2 ).

The hypereutrophic treatment showed lowest $\mathrm{pH}$ values, but in general, $\mathrm{pH}$ values were always 
Table 2. Results of one-way ANOVAs testing the effects of treatments (mesotrophic, eutrophic and hypereutrophic), experiment days (days 1,7 and 14) and their interaction term on the density of zooplankton.

\begin{tabular}{|c|c|c|c|c|}
\hline \multirow[t]{2}{*}{ Zooplankton } & \multicolumn{4}{|c|}{ ANOVA results } \\
\hline & Effect & $F$ & df & $p$ \\
\hline \multirow{4}{*}{ Moina minuta } & Treatments $(T)$ & 19.82 & 2 & $<0.001$ \\
\hline & Days (D) & 18.22 & 2 & $<0.001$ \\
\hline & $T \times D$ & 15.89 & 4 & $<0.001$ \\
\hline & Residual & & 17 & \\
\hline \multirow{4}{*}{ Latonopsis sp. } & Treatments $(T)$ & 2.27 & 2 & $n s$ \\
\hline & Days (D) & 32.57 & 2 & $<0.001$ \\
\hline & $T \times D$ & 0.71 & 4 & $n s$ \\
\hline & Residual & & 17 & \\
\hline \multirow{4}{*}{ Brachionus urceolaris } & Treatments $(T)$ & 11.92 & 2 & $<0.001$ \\
\hline & Days (D) & 12.37 & 2 & $<0.001$ \\
\hline & $T \times D$ & 13.33 & 4 & $<0.001$ \\
\hline & Residual & & 17 & \\
\hline \multirow{4}{*}{ Thermocyclops sp. } & Treatments $(\mathrm{T})$ & 3.57 & 2 & $n s$ \\
\hline & Days (D) & 12.43 & 2 & $<0.001$ \\
\hline & $T \times D$ & 4.57 & 4 & $<0.05$ \\
\hline & Residual & & 17 & \\
\hline \multirow{4}{*}{ Hexarthra mira } & Treatments $(\mathrm{T})$ & 2.8 & 2 & $n s$ \\
\hline & Days (D) & 5.31 & 2 & $<0.05$ \\
\hline & $T \times D$ & 10.73 & 4 & $<0.001$ \\
\hline & Residual & & 17 & \\
\hline \multirow{4}{*}{ Náuplio } & Treatments $(\mathrm{T})$ & 18.93 & 2 & $<0.001$ \\
\hline & Days (D) & 139.04 & 2 & $<0.001$ \\
\hline & $T \times D$ & 9.90 & 4 & $<0.001$ \\
\hline & Residual & & 17 & \\
\hline
\end{tabular}

ns: non-significant.

alkaline, and tended to increase throughout the study period (Figure 2).

With data from all species pooled together, the two-way MANOVA procedure revealed significant differences among sampling days and among treatments. Also, the interaction between these two factors was significant, suggesting that the observed variation in trophic concentrations were related to temporal variations (Table 3).

Results of univariate ANOVAs are shown in Table 2. Density of Latonopsis sp. varied only among sampling days. Density of both $H$. mira and Thermocyclops sp. varied significantly among sampling days and for the interaction term between treatment and sampling days, but not for treatments. Further, density of Latonopsis sp. varied significantly only among sampling days (Table 2).

Results of Generalized Linear Models suggest that $\mathrm{pH}$ and trophic states were major determinants of zooplankton concentrations (Table 4).

Analysis of the relative abundances of algae species in the end of the experiment revealed the following patterns: mesotrophic treatment (Scenedesmus acuminatus: 64\%; Scenedesmus

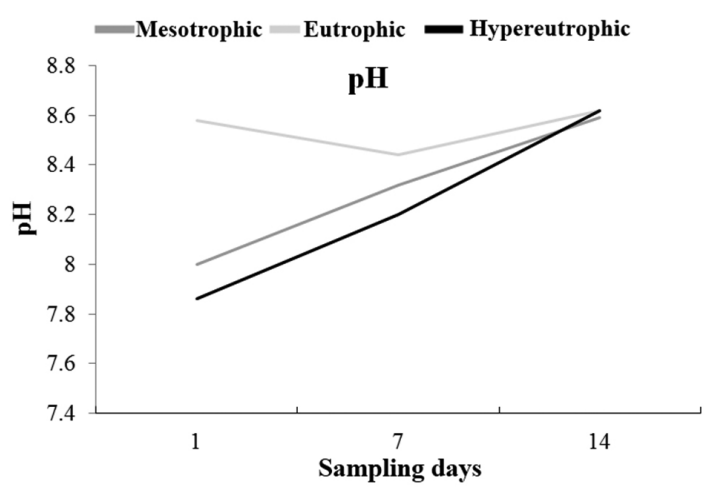

Figure 2. Temporal variations of $\mathrm{pH}$ on three experimentally simulated trophic conditions (mesotrophic, eutrophic and hypereutrophic).

bijugatus: 20\%; Chorella sp.: 10.2\% and an unidentified algae: 5.8\%); eutrophic treatment (Aphanotece sp.: 42.2\%; Chrococus sp.: 28.6\%; Scenedesmus sp.: $15.2 \%$ and Chlorella sp.: 14\%) and hypereutrophic treatment (S. bijugatus: 41\%; Chlorella sp.: 22\%; Merismopedia sp.: 10\% and an unidentified algae: $27 \%$ ). 
Table 3. Results of factorial MANOVA testing the effects of treatments (mesotrophic, eutrophic and hypereutrophic), experiment days (days 1, 7 and 14) and their interaction term on the density of zooplankton species (Moina minuta, Latonopsis sp., Brachionus urceolaris, Hexarthra mira and Thermocyclops sp.) and nauplii pooled together.

\begin{tabular}{ccccc}
\hline Effect & Wilk's lambda & $\mathbf{F}$ & df & $\boldsymbol{p}$ \\
\hline Treatments (T) & 0.03 & 10.58 & 12 & $<0.001$ \\
Days (D) & 0.01 & 36.99 & 12 & $<0.001$ \\
T $\times$ D & 0.01 & 5.18 & 24 & $<0.001$ \\
\hline
\end{tabular}

Table 4. Results of Generalized Linear Models (GLMs) testing the effects of $\mathrm{pH}$ and trophic states on the total density of five zooplankton taxa (Moina minuta, Latonopsis sp., Brachionus urceolaris, Hexarthra mira and Thermocyclops sp.) pooled together.

\begin{tabular}{lcccc}
\hline \multirow{2}{*}{ Predictors } & \multicolumn{5}{c}{ GLM Results } \\
\cline { 2 - 5 } & Wilk's lambda & F & df & $\boldsymbol{p}$ \\
\hline $\mathrm{pH}$ & 0.69 & 1.43 & 1 & $n s$ \\
Trophic states & 0.23 & 3.44 & 2 & $<0,01$ \\
\hline
\end{tabular}

ns: non-significant.

\section{Discussion}

The significant decrease in the density of $B$. urceolaris throughout the study is likely to be an effect of their negative acclimation to the culture mediums. It is well known that zooplankton species may not always ideally cope with laboratory conditions, given stress-induced factors interfering with reproductive rates and, thus, density growth ( Sarma and Nandini, 2001). As in the present investigation, several studies also found positive correlations between Brachionus species and eutrophic conditions (Gannon and Stemberger, 1978; Sládeck, 1983; Blancher, 1984; Berzins and Pejler, 1989; Matsumura-Tundisi et al., 1990; Pontin and Langley, 1993; Torres-Orozco and Zanatt, 1998).

Furthermore, results of the present study suggest that Rotifers are typical of nutrient-rich environments, as previously acknowledged on a tropical semiarid reservoir (Vieira et al., 2009).

The observed distribution patterns of the cladoceran Latonopsis sp. may be attributed to its ticoplanktonic habits, therefore closely associating to substrates where it feeds on particulate organic matter (Lansac-Tôha et al., 2004). Given that the culture mediums favored algal and organic matter deposition, this species may have been positively influenced by these processes. Nonetheless, the eutrophic treatment showed higher density concentrations than did the other treatments.

Peak densities decrease of $M$. minuta observed on the mesotrophic treatment (i.e. after 60 ind. $\mathrm{L}^{-1}$ ) may have been due decrease in available food (due high density) and limited space. Since population growth is constrained by the physical space available on each culture medium this observed decrease may be easily justified (Vieira et al., 2011).

As with other cyclopoids, Thermocyclops are most abundant in nutrient-rich environments and results of the present study are consistent with those observed at semi-arid reservoirs (e.g. Leitão et al., 2006). Cyclopoids actively feed on rotifers (Rao and Kumar, 2002), and their increase is likely to be an effect of higher rotifer densities observed on the eutrophic and hypereutrophic treatments. Density of nauplii also increased on nutrient-rich samples. The effect of high nutrient concentration increasing the density of cyclopoids is well known (Silva et al., 2009). Our results suggest that nauplii growth, a consequence of cyclopoid reproduction, reduced on samples with high adult population densities, particularly on the eutrophic treatment. Therefore, the experiment supports what is observed in the field, in which cyclopoids initially benefit from an increase in trophic concentration, as revealed by the rapid increase in nauplii density, and, subsequently, the high population density constrains an ongoing reproduction (Blancher, 1984; Matsumura-Tundisi et al., 1990; TorresOrosco and Zanatt, 1998). These observations suggest that longer experimental periods would result in a shift from a high nauplii concentration to a high adult concentration.

The increase in $\mathrm{pH}$ levels on the three treatments may have been due to the increased photosynthetic activities of algae consuming carbon dioxide and influencing $\mathrm{pH}$ levels (Esteves, 1998).

Comparison of algae composition between the beginning and the end of the experiment reveals community-level modifications. For example, containers subject to higher trophic levels showed higher abundance of cyanobacteria. Individuals of Aphanotece sp. dominated, and on the hypereutrophic treatment, Merismopedia sp. showed a somewhat high abundance (i.e. 10\% of total abundance), albeit it was not detected in the beginning of the study. Therefore, algal density 
played an important role, affecting (positively or negatively) different zooplankton species.

Furthermore, zooplankton species which are positively influenced by eutrophization, are ecological valuable at indicating pollution (Avila et al., 2009). Given that, nutrients play a direct role on primary production and algal density, affecting zooplankton via trophic cascades, it is possible to predict zooplankton numbers, and to a certain extent, overall zooplankton composition, from samples with different nutrient concentrations (Horppila, 1998). Our experiment highlights these well-documented patterns in aquatic ecology using experimental manipulation approaches conducted under controlled laboratory simulations.

\section{Acknowledgments}

We are grateful to Dr. Paulo R. Medeiros for reviewing the manuscript, MSc. Maria Marcolina for laboratory assistance and to CNPq, CAPES and PELD for providing financial support.

\section{References}

AGUIAR, DG., AZEVEDO, SMFO. 1998. Effect of different nutrient concentrations on growth and hepatotoxin production by Microcystis aeruginosa (Cyanobacteria). Verhandlungen des Internationalen Verein Limnologie, vol. 26, p. 1637-1658.

ANDERSON, D.M. 1989. Toxic algal blooms and red tides: a global perspective. In Red Tides: Biology, Environmental Science, and Toxicology. New York: Elsevier. p. 11-16.

ANDERSON, DM., GILBERT, PM. and BURKHOLDER, JM. 2002. Harmful algal blooms and eutrophication: nutrient sources, composition, and consequences. Estuaries, vol. 25, p. 704-726. http://dx.doi.org/10.1007/BF02804901

AVILA, TR., PEDROZO, CS. and BERSANO, JGF. 2009. Temporal variation of the zooplankton from Tramandaí Beach, RS, southern Brazil, with emphasis on Copepoda. Iheringia, Série Zoologia, vol. 99, no. 1.

BEASLEY, VR., COOK, WO., DAHLEM, AM., HOOSER, SB., LOVELL, RA. and VALENTINE, WM. 1989. Intoxication in livestock and water fowl. Veterinary Clinics of North America: Food Animal Practice, vol. 5, p. 345-361. PMid:2503241.

BLANCHER, EC. 1984. Zooplankton trophic relationships in some north and central Florida lakes. Hydrobiologia, vol. 109, p. 251-263. http://dx.doi. org/10.1007/BF00007743

BERZINS, B. and PEJLER, B. Rotifer occurrence and trophic degree. 1989. Hydrobiologia, vol. 182, p.171180. http://dx.doi.org/10.1007/BF00006043
BEZERRA-NETO, JF. 2001. A influência da larva de Chaoborus (Insecta: Diptera) na distribuição espacial da comunidade zooplanctônica na Lagoa do Nado, Belo Horizonte-MG. Belo Horizonte: Universidade Federal de Minas Gerais. [Dissertação de Mestrado].

BICUDO, CEM. and MENEZES, M. 2006. Gênero de algas de águas continentais do Brasil - Chave para identificação e descrição. 2. ed. São Carlos: Rima.

CARPENTER, SR., KITCHELL, JE. and HODGSON, JR. 1985. Cascading trophic interactions and lake productivity. Bioscience, vol. 35, p. 634-639. http:// dx.doi.org/10.2307/1309989

CLESCERI, L.S., GREENGERG, A.G. and EATON, A.D. 1998. Standard Methods of the Examination of Water and Wastewater. 20. ed. Washington: APHA, AWWA, WEF.

CRISPIM, M.C., LEITE, R.L. and WATANABE, T. 2000. Evolução do estado trófico em açudes temporários no Nordestes semi-árido, durante um ciclo hidrológico, com ênfase na comunidade zooplanctônica. Anais do V Simpósio de Ecossistemas Brasileiros, 2000. vol. 3, p. 431-441.

ELMOOR-LOUREIRO, LMA 1997. Manual de identificação de cladóceros límnicos do Brasil. Brasília: Universa. 156 p.

ESTEVES, FA. 1998. Fundamentos de Limnologia. 2. ed. Rio de Janeiro: Interciência.

FELICIANO, MLM. and MELO, RB. 2003. Atlas do estado da Paraíba: informação para gestão do patrimônio natural. João Pessoa: SEPLAN/IDEME. $58 \mathrm{p}$.

FIGUEIRÊDO, MCB., TEIXEIRA, AS., ARAÚJO, LFP., ROSA, M F., PAULINO, W. D., MOTA, S. and ARAÚJO, JC. 2007. Avaliação da vulnerabilidade ambiental de reservatórios à eutrofização. Revista Engenharia Sanitária e Ambiental, vol. 12, p. 399409.

FORRESTER, GE., DUDLEY, TL. and GRIMM, NB. 1999. Trophic interactionsin open systems: Effects of predators and nutrients on stream food chains. Limnology and Oceanography, vol. 44, no. 5, p. 1187 1197. http://dx.doi.org/10.4319/lo.1999.44.5.1187

GANNON, JE. and STEMBERGER, RS. 1978. Zooplancton ( Especially Crustaceans and Rotifers) as Indicators of water Quality. Transactions of the American Microscopical Society, vol. 97, no. 1, p. 1635. http://dx.doi.org/10.2307/3225681

HORPPILA, J. 1998. Top-down or bottom-up effects by fish: issues of concern in biomanipulation of lakes. Restoration Ecology, vol. 6, p. 20-28. http://dx.doi. org/10.1046/j.1526-100x.1998.00613.x

HUSZAR, VLM., SILVA, LHS., DOMINGOS, P., MARINHO, M. and MELO, S. 1998. Phytoplankton species composition is more sensitive than OECD criteria to the trophic status of three Brazilian tropical 
lakes. Hydrobiologia, vol. 369-370, p. 59-71. http:// dx.doi.org/10.1023/A:1017047221384

KELLY, M G. and WHITTON, BA. 1998. Biological monitoring of eutrophication in rivers. Hydrobiologia, vol. 384, p. 55-67. http://dx.doi. org/10.1023/A:1003400910730

KOSTE, W. 1978. Rotatoria. Berlin: Gebruder Borntraeger. $673 \mathrm{p}$.

LANSAC-TÔHA, FA., VELHO, LFM. and BONECKER, CC. 2004. Composition, species richness and abundance of the zooplankton community. In THOMAZ, SM. and AGOSTINHO, AA., eds. The Upper Paraná River and itsfloodplain: physical aspects, ecology and conservation. Leiden: Backhuys Publishers. p. 145-190.

LEITÃO, AC., FREIRE, RHF.ROCHA, O. and SANTAELLA, ST.2006. Zooplankton community composition and abundance in two Brazilian semiarid reservoirs. Acta Limnologia Brasiliensia, vol. 18, no. 4, p. 451-468.

MacKERETH, FJH., HERON, J. and TALLING, J.F. 1978. Water analysis: some revised methods for limnologists. Freshwater Biological Association Scientific Publication, vol. 3, no. 36, p. 1-121.

MARESOVIC, I. and PUCHER-PETKOVIC, T., 1991. Eutrophication impact on the species composition in a natural phytoplankton community. Acta Adriatica, vol. 32, p. 719-730.

MATSUMURA-TUNDISI, T., NEUMANN-LEITÃO, S., AGUENA, LS. and MIYAHARA, J. 1990. Eutrofização da represa de Barra Bonita: estrutura e organização da comunidade de Rotifera. Brazilian Journal of Biology, vol. 50, no. 4, p. 923-935.

MOSS, B. 1998. Shallow Lakes, biomanipulation and eutrophication. Bruxelas: SCOPE. Newsletter, CEFIC (European Chemical Industry Council). 44 p.

Organisation for Economic Co-operation and Development - OECD. 1982. Eutrophication of waters - monitoring, assessment and control. Paris: OECD.

PONTIN, R. M. and LANGLEY, J. M. 1993. The use of rotifer communities to provide a preliminary national classification of small water bodies in England. Hydrobiologia, vol. 255-256, p. 411-419. http:// dx.doi.org/10.1007/BF00025866

RAO, TR. and KUMAR, R. 2002. Patterns of prey selectivity in the cyclopoid copepod Mesocyclops thermocyclopoids. Aquatic Ecology, vol. 36, no. 3, p. 411424. http://dx.doi.org/10.1023/A:1016509016852

RAVERA, O. 1980. Effects of eutrophication on zooplankton. Progress in Water Technology, vol. 13, p. 141-159.

REID, J W. 1985. Chave de identificação e lista de referências bibliográficas para as espécies continentais sulamericanas de vida livre da ordem Cyclopoida
(Crustacea: Copepoda). Boletim de Zoologia da Universidade de São Paulo, vol. 9, p. 17-43.

ROCHA, O. and MATSUMURA-TUNDISI, T. 1976. Atlas do zooplâncton (Represa do Broa, São Carlos). São Carlos: Universidade Federal de São Carlos. 68 p.

RODIER, JL. 1975. Analyse de l'eau: eaux naturelles, eaux residuals, eaux de mer. Paris: Dunod.

ROYSTON, JB.1983. Some techniques for assessing multivariate based on the Shapiro-Wilk W. Applied Statistics, vol. 32, p. 33-121.

RIEGMAN, R. 1995. Nutrient-related selection mechanisms in marine phytoplankton communities and the impact of eutrophication on the planktonic food web. Water Science and Technology, vol. 32, p. 63-75. http://dx.doi.org/10.1016/02731223(95)00682-6

SARMA, SSS. and NANDINI, S. 2001. Life Table demography and population growth of Brachionus variabilis Hempel, 1896 in relation to Chlorella vulgaris densities. Hydrobiologia, vol. 446-447, p. 75-83. http://dx.doi. org/10.1023/A:1017577206815

SCHEFFER, M. 1998. Ecology of Shallow Lakes. Chapman \& Hall. 357 p.

SEIP, K. L. 1991. Phosphorus and nitrogen limitation of algal biomass across trophic gradients. Aquatic Sciences, Research Across Boundaries, vol. 56, p. 10151621.

SILVA, WM., 2003. Diversidade dos Cyclopoida (Copepoda, Crustacea) de água doce do estado de São Paulo: taxonomia, ecologia e genética. Universidade Federal de São Carlos. 154 p. [Tese de Doutorado].

SILVA, LHS. 1999. Fitoplâncton de um reservatório eutrófico (lago Monte Alegre), Ribeirão Preto, São Paulo, Brasil. Brazilian Journal of Biology, vol. 59, p. 281-303.

SILVA, AMA., BARBOSA, JEL., MEDEIROS, PR., ROCHA, RM., LUCENA-FILHO, MA. and SILVA, DF. 2009. Zooplankton (Cladocera and Rotifera) variations along a horizontal salinity gradient and during two seasons (dry and rainy) in a tropical inverse estuary (Northeast Brazil). Pan-American Journal of Aquatic Sciences, vol. 4, p. 226-237.

SILVA, WM. and MATSUMURA-TUNDISI, T. 2005. Taxonomy, ecology and geographical distribution of the genus Thermocyclops Kiefer, 1927 (Copepoda, Cyclopoida) in São Paulo State, Brazil, with description of a new species. Brazilian Journal of Biology, vol. 65, no. 3, p. 521-531. PMid:16341431. http://dx.doi. org/10.1590/S1519-69842005000300018

SLÁDECK, V. 1983. Rotifers as indicators of water quality. Hydrobiologia, vol. 100, p. 169-201. http:// dx.doi.org/10.1007/BF00027429

STEMBERG, R. 1979. A guide to Rotifers. Cincinnati: Environmental Monitoring and Support Laboratory. 
TORRES-OROZCO, RE. and ZANATT, S.A. 1998. Species composition, abundance and distribution of zooplankton in a tropical eutrophic lake: Lake Catemaco, México. Revista de Biologia Tropical, vol. 46 no. 2, p. 285-296.

VIEIRA, ACB., RIBEIRO, LL., SANTOS, DPN. and CRISPIM, MC. 2009. Correlation between the zooplanktonic community and environmental variables in a reservoir from the Northeastern semi-arid. Acta Limnologica Brasiliensia, vol. 21, p. 349-358.

VIEIRA, ACB., MEDEIROS, AMA., RIBEIRO, LL. and CRISPIM, MC. 2011. Populations dynamics of Moina minuta Hansen (1899), Ceriodaphnia cornuta Sars (1886), and Diaphanosoma Spinulosum Herbst (1967) (Crustacea: Branchiopoda) in different nutrients $(\mathrm{N}$ and $\mathrm{P})$ concentration ranges. Acta Limnologica Brasiliensia, vol. 23, no. 1, p. 1-9.

Received: 28 July 2012 Accepted: 27 September 2013 